\title{
New developments in the pathology of malignant lymphoma: a review of the literature published from April 2010-July 2010
}

\author{
J. Han van Krieken
}

Published online: 5 October 2010

(C) Springer-Verlag 2010

\section{Introduction}

It is obviously impossible to review all the literature on lymphoma. Also, the past months several hundreds of papers have been published dealing with a variety of topics. In this review, a focus on those papers that are of interest for hematopathologists resulted in about 70 articles. Excluded are articles on treatment, which are many, and articles that deal with very fundamental biology. Both categories are obviously also of potential interest to pathologists but in a more indirect way. When insights from cell biology translate into clinical application these topics meet in pathology and thus are the topic of this series of reviews.

\section{Biology of lymphoma}

\section{Hodgkin's lymphoma}

Hodgkin's lymphoma (HL) remains a curious disease in which undoubtedly environmental factors are important but familial occurrence indicates a germline genetic contribution too. Timms et al. [1] encountered a family with many HL patients and a balanced germline translocation, from which they cloned an unknown gene, KLHDC8B. Deficiency of this gene, a Kelch family protein, leads to disturbed cytokinesis and binucleated cells, which obviously may explain the occurrence of Reed-Sternberg cells in

J. H. van Krieken $(\bowtie)$

Department of Pathology, Radboud University Nijmegen, Medical Center,

P.O. Box 9101, 6500 HB Nijmegen, The Netherlands

e-mail: j.vankrieken@pathol.umcn.nl
HL. Their data also suggest that disruption of this gene may explain the increased occurrence of twins in families with increased HL.

The other curiosity, next to the binucleated cells, is the fact that the tumors consist of many more inflammatory cells than tumor cells. The importance of the microenvironment is well known and one reason in Epstein-Barrvirus (EBV)-positive cases is the expression of HLA class I and II on tumors cells, which attracts, in concert with other proteins, immune cells. Huang et al. [2] investigated 145 HL samples from China and demonstrate a high percentage of HLA I in EBV-positive cases, like in Western cases, but a lower percentage of class II. Nevertheless, the composition of the inflammatory background was not different, downplaying the potential role of HLA class II in determining the tumor environment.

\section{B-cell lymphomas}

The use of mouse models to discover factors involved in lymphomagenesis has revealed much insight how lymphocytes transform. A key factor is cell survival, especially in lymphocytes, that are normally prone to apoptosis. Osborne et al. [3] use transgenic and knockout mice and had already found that IL-7 overexpression results in lymphoma development. Now, they describe that loss of function of the IL-7 receptor-alpha results in suppression of lymphomagenesis by suppressing survival of regulatory T-cells (T-reg), indicating the importance such "bystander" cells for lymphoma development. The importance of T-cells for sustaining B-cell lymphoma cells was already known from elegant studies by the group of Peter Isaacson on Helicobacter pylori (HP) and gastric marginal zone lymphoma (MALT-lymphoma). Indeed Craig et al. [4], using a mouse model of HP induced 
MALT-lymphoma, show that in vitro the T-regs are needed for growth of the lymphoma B-cells and that the interaction takes places through the CD40-CD40 ligands binding. These results explain the success of the wellknown treatment for gastric MALT-lymphoma by HPeradication. Niino et al. [5] describe successful antibiotic treatment in 5/8 cases of rectal MALT-lymphoma. In two cases that were not responsive, the involvement of MLT-1 was shown. How MALT-lymphomas of the stomach and rectum with MLT-1 breaks escape the need for T-cell for survival remains unknown.

In normal B-cells, there is an inverse relationship between bcl-2 and Ki67 expression. According to Masir et al. [6] this inverse relationship is maintained in low-grade B-cell lymphomas, even when they transform, while in mantle cell lymphoma (MCL) and diffuse large B-cell lymphoma (DLBL) they are often coexpressed.

MCL is a well-characterized and extensively studied lymphoma type. One of the features is resistance to apoptosis, which is not well explained. According to Martin-Perez et al. [7] the polycomb protein SUZ12, which targets cell survival genes, is an important factor, since it is overexpressed, partially due to gene amplification; maybe partially through microRNA's (miR), like in MYC negative Burkitt lymphoma where they mimic MYC action [8]. In fact, Di Lisio [9] from the same group studied miR in MCL and found a characteristic expression profile, involving genes miRs that target pathways relevant for cell survival. Especially miR-26a, which regulates NF-kappaB, seems important. They were also able to create a miR prognostic signature. In this paper, there is no mention of the polycomb proteins.

Many new drugs are being tested for different forms of cancer. Although it is well known that an effect of drugs on cancer cell lines is not a good indicator for effect in patients, these models are still good first step. Drugs that affect epigenetic changes, like histone deacetylase (HDAC), are very promising. Dasmahapatra [10] show that in DLBL cells, both activated $\mathrm{B}(\mathrm{aB})$ and germinal center $(\mathrm{GC})$ type and mice with DLBL, a HDAC inhibitor (vorinostat), potentiates the effect of a proteasome inhibitor (carfilzomib).

Bcl-6 is an important molecule in DLBL. One of the actions is repression of PDCD2, a protein that induces apoptosis [11]. Indeed a small molecule that inhibits bcl-6 results in death of DLBL cells [12].

The relative ease by which cells can be obtained using fine-needle aspiration (FNA) was used by Tang et al. [13] to study Burkitt's lymphoma (BL) cells before, and during therapy. They were able to show that EBV-positive BL enters the lytic phase under cyclophosphamide therapy, providing a rationale for combination treatment with ganciclovir; this may be applicable to EBV-positive lymphomas in immune deficient patients too.

\section{T-cell lymphoma}

The genetics of T-cell lymphomas is much less known compared to B-cell lymphoma. Recently, the chromosomal translocation $\mathrm{t}(5,9)(\mathrm{q} 33 ; \mathrm{q} 22)$ generating the interleukin-2 (IL-2)-inducible T-cell kinase (ITK)-spleen tyrosine kinase (SYK) fusion tyrosine kinase was identified as a recurrent event in peripheral T-cell lymphoma (PTCL). Pechloff et al. [14] show that ITK-SYK associates with lipid rafts in Tcells and triggers antigen-independent phosphorylation of T-cell receptor (TCR)-proximal proteins. These events lead to activation of downstream pathways and acute cellular outcomes that correspond to regular TCR ligation, including up-regulation of CD69 or production of IL-2 in vitro or deletion of thymocytes and activation of peripheral T-cells in vivo. By introducing the fusion product in mice, they also developed a mouse model for PTCL. These important studies will certainly lead to a much better understanding of T-cell lymphoma development.

Ataxia teleangiectasia is a disease due to defective DNA repair leading to lymphomas at young age. An important mechanism is the disturbed repair of double strand breaks that occur in lymphocyte maturation (T- and B-cell receptor rearrangement). Lymphomas in these patients are characterized by translocations involving the antigen receptor genes, but according to Zha et al. [15] also to aberrant TCRdelta rearrangement to the centromer and gene amplification.

The investigation of the cellular composition of lymphomas has already given many ideas about the pathogenesis. Schlapbach et al. [16] investigated the presence of dendritic cell (DC) subsets in mycosis fungoides (MF). There was a large increase in the number of immature DCs (DC-SIGN+) which by their immune tolerance inducing capacity might protect the tumor cells from immune attack.

The importance of the immune system in cutaneous lymphoma is also exemplified by the work of Kopp et al. [17] who demonstrated expression of COX-2 in advanced MF and cell lines of MF, whereas in early stage MF there is no expression. COX-2 expression induces prostaglandin $\mathrm{E}$ in immune cells expression which is a growth promoting protein.

\section{Epidemiology of lymphoma}

Understanding the cause of disease is a main step towards cure and preferably prevention. Herpes viruses are involved in several lymphoma types and recently it was shown that polyoma virus is associated with Merkel cell carcinoma of the skin, not the lung [18]. Anders et al. [19] investigated whether the Merkel cell Polyomavirus DNA is present in cutaneous lymphomas, pseudolympho- 
mas and inflammatory skin disease and show that overall $8-17 \%$ of the biopsies carry the DNA, implying that the virus is not likely to be involved in the lymphomagenesis. Although this is a negative finding such studies are important, and the strength of this paper is the proper controls that were used.

Iyengar et al. [20] collected all their cases of HL from the head and neck region, which were 39 cases in 40 year, indicating its rareness. Ten of the 34 patients with classical HL had disease in the tonsils, nine in the nasopharynx, eight in the thyroid, three in the parotid, two in the adenoids, and one each in Waldeyer's ring and nasal antrum. Median age at diagnosis was 31.5 years, average age at diagnosis was 38 years, and 22 of 34 were male; 23 had stage I or II disease. Pathologically, 14 of 34 had the nodular sclerosis subtype, whereas 15 had mixed cellularity. Twenty-nine of 34 had nodal neck disease at presentation. Clinical data indicate that HL presenting at this site is very similar to other sites.

For patients who have survived cancer for 5 years, it is important to know whether they are really cured and if not, how their prognosis is. The study of Larouche et al. [21] is therefore an important one: they find in patients with DLBL very few relapse later than 5 years (about $3 \%$ of all patients who present with DLBL). However, when these patients relapse with again DLBL their prognosis is poor (5-year survival of about $25 \%$ ); in case the relapse is a low-grade lymphoma, the outcome is much better, indicating the importance of a pathological investigation after late recurrences.

There is a large variation with respect to lymphoma type and outcome between different regions of the world. Such differences indicate causes of the lymphoma and thus are important to document. A retrospective analysis of cases in Tanzania show that all lymphoma types occur, and that HIV-associated EBV-positive lymphomas are common. Mwakigonia et al. [22] conclude that therefore the Western approach with respect to classification and treatment of lymphomas is, when possible, applicable in Tanzania. In a similar study from Uganda Turnwine et al. [23] showed in general the same, but the exception was a very high percentage of EBV in Burkitt's lymphoma, and much fewer HIV-associated lymphomas than expected.

Li et al. [24] used the Hans' algorithm and FISH on 63 cases of DLBL and conclude that in northern China, the frequency of the GC type and BCL6 expression and/or BCL6 rearrangement is less and the frequency of MYC rearrangement is greater than have been reported in Western countries. In China, thyroid lymphomas were also studied, like in other countries (see previous review, van Krieken [25]). Sun et al. [26] studied 40 cases and show that combined chemotherapy and radiotherapy may offer better outcome without the need for extensive resection, and surgery should be reserved to providing tissue for diagnosis. The patients with low-intermediate risk (IPI=2) or stage IIE need be treated more aggressively.

In Japan, adult T-cell leukemia/lymphoma is relatively common. Takasaki et al. [27] analyzed the outcome in 90 patients who presented with indolent disease. They found however, that the disease in this group is more aggressive than expected and that prognostic factors that apply for lymphomas in general apply in this group too. A more aggressive therapeutic approach may be needed for these patients.

Cutaneous lymphomas in Taiwan have a very different type distribution compared to Western countries. Based on 56 cases with skin involvement, including 31 primary skin lymphomas, Liao et al. [28] conclude that NK/T-cell lymphomas of nasal type are more common, while B-cell lymphomas are rarer.

\section{Defining entities}

Classification of lymphomas is based on multiple factors. Andreasson et al. [29] argue that investigation of purified B-cell lymphoma cells by gene expression arraying may give a new possibility of classifying lymphomas. So far, they were able to show that this approach leads to the finding of transcription factors that are specifically altered in certain lymphoma types, like MCL and CLL.

\section{B-cell lymphomas}

Kojima et al. [30] report on nine cases of EBV-positive lymphoproliferations presenting in Waldeyer's ring. Their article shows the different approach in Japan compared to Western countries, by describing the lesions as lymphomalike where the WHO classification does not use this term in such cases. The article points out that in these lesions the morphology of MALT-lymphomas may occur.

Liu et al. [31] report on the transformation into DLBL of low-grade MALT-lymphomas. In their series, this rarely happened (1/55); including 13 that were refractory to HPeradication (no genetic data were given).

CyclinD1 identifies MCL with great reliability; nevertheless, Kraus et al. [32] investigated whether CD11c expression as determined by flow cytometry may be of additional help in discriminating MCL from CLL. They found a very low percentage of CD11c expression in MCL (2/44) while $27 \%$ of CLL were positive.

Rizzo et al. [33] investigated 41 nodal and extranodal MZL in children and young adults (15-29 years of age) using FISH and immunohistochemistry. Although a lower percentage of cases had detectable genetic alterations, the 
data indicate that these lymphomas are not different from the adult counterparts.

My previous reviews included several papers regarding the determination of the $A B$ versus the $G C$ type of DLBL. Nevertheless, there is still not an easy and reliable method. Dumick et al. [34] studied 101 de novo DLBL by immunohistochemistry and FISH. Even though they had no gold standard, they conclude that expression of LMO2, a germinal center marker is a good surrogate for the GC type.

Deregulation of the STAT-3 pathway is known to play a critical role in AB type of DLBCL, with a low expression associated with high bcl-2 indicating poor prognosis. Since the majority of the primary central nervous system lymphomas (PCNSL) are of the $\mathrm{AB}$ type Vajpavee et $\mathrm{Al}$. [35] studied the immunohistochemical expression of STAT3 proteins in PCNSL along with other traditional markers (CD10, bcl-6, MUM-1 and bcl-2) in 17 cases of PCNSL occurring in immunocompetent patients. Despite lack of STAT-3 expression in all cases, the majority (70\%) of the patients with bcl-2 positive PCNSL had an adverse outcome similar to that reported in systemic lymphomas of $\mathrm{ABC}$ subtype. Based on their observations they propose that PCNSL represents a distinct subset of $\mathrm{ABC}$ diffuse large B-cell lymphomas with low STAT-3 expression and perhaps mechanisms other than interaction of STAT-3 and NF-kappaB pathways may play a role in up regulation of bcl-2 in PCNSL.

Partly due to the SH workshop in Cleveland, plasmablastic lymphoma has become a topic of interest. First, it is important to recognize and diagnose this lymphoma type reliably. According to Monter-Moreno et al. [36], after comparing 35 cases with 111 DLBL, staining with PAX5, CD20, PRDM1/BLIMP1, and XBP1 enables the identification of a plasmablastic immunophenotype highly characteristic of plasmablastic lymphoma cases and associated with an aggressive clinical behavior. Additionally, the study shows that the acquisition of a partial plasmablastic phenotype (PRDM1/BLIMP1 expression) in DLBCL is associated with shorter survival in R-CHOP-treated patients. Taddesse-Heath et al. [37] investigated four cases of HIV-associated plasmablastic lymphomas by immunohistochemistry and FISH for MYC breaks. They conclude that these cases have overlapping features with plasmablastic dedifferentiated myelomas: in fact all cases had a MYC break, which is rare in plasmablastic lymphoma but common in aggressive multiple myeloma.

MYC rearrangements are now most often sought for using split signal probes. However, as described by May et al. [38], in aggressive DLBL aberrant rearrangements may occur, that can only be detected by three color dual fusion approach. This latter remark is stressed by the findings of Keleman et al. [39] who show that Burkitt lymphoma (BL) about $10 \%$ have aberrant phenotype: lacking surface immunoglobulin, and either B-cell antigen or CD10. The caveat however is that all cases were immune deficiency associated, and it is known that such lymphomas commonly have deviations from lymphomas that arose in immunecompetent individuals.

There was, until recently, no reliable antibody for MYC in paraffin sections. According to Ruzinova et al. [40], such an antibody is available now. They studied $17 \mathrm{BL}$, (15 cases with confirmed MYC translocation), 19 DLBCLs without a MYC translocation, five DLBCLs with a MYC translocation, and two B-cell lymphomas, unclassifiable, with features intermediate between DLBCL and BL (intermediate DBLCL/BL, one with MYC). There was MYC expression in the tumor cells of all cases regardless of MYC status. Among BLs, c-MYC protein primarily localized to the nucleus of tumor cells in 15 of 17 cases $(88 \%)$ and equally localized to the nucleus and cytoplasm of tumor cells in 2 of 17 cases (12\%). In contrast, among DLBCLs lacking a MYC translocation the c-MYC protein primarily localized to the cytoplasm of the tumor cells in 18 of 19 cases (95\%) and equally localized to the nucleus and cytoplasm in the tumor cells in 1 of 19 cases (5\%). Among DLBCLs with a MYC translocation and intermediate DBLCL/BLs, the c-cMYC protein primarily localized to the nucleus, or equally localized to the nucleus and cytoplasm of the tumor cells in four of five cases $(80 \%)$ and two of two cases $(100 \%)$, respectively. These data indicate that primarily nuclear or mixed nuclear and cytoplasmic staining pattern for c-MYC in an aggressive B-cell lymphoma is highly predictive of a c-MYC translocation: so life for pathologists might become easier after all. Or not? If copy number changes are relevant, FISH is still needed. Stasik et al. [41] find that increased MYC copies are related to increased mRNA levels and poor outcome based on 52 cases of DLBL. Presently, however, this is no strong-enough data to introduce FISH for this purpose in routine practice.

\section{Cutaneous lymphomas}

The distinction of a primary cutaneous MZL from secondary involvement is quite relevant, since the former is an indolent localized disease requiring relatively minimal local treatment. Gerami et al. [42] investigated four secondary skin MZL and compared these with 30 primary MZL but did not find any morphological or immunophenotypical difference. Clinical data therefore remain the crucial issue.

Another difficult but important issue is the discrimination of primary cutaneous large B-cell lymphomas (PCLBL), leg type, from primary cutaneous follicle center lymphoma 
(PCFCL). Koens et al. [43] describe a surprisingly easy method, namely the immunohistochemical detection of IgM, which was found in all 40 large cell lymphomas and in only five out of 53 PCFCL; curiously enough, three of these latter five presented on the leg. It is not yet clear if IgM-positive PCFCL, leg type, is a separate entity.

Braghavati et al. [44] studied ten cases of PCLBL in order to gain insight in the pathogenesis of this lymphoma that most often present in elderly patients. Only $1 / 10$ cases was EBV-positive and 7/10 had an activated NF-kappaB pathway.

The MF variant folliculotropic MF is relatively poorly characterized. Lehman et al. [45] collected 58 cases over a 12 year period and reviewed the literature on this entity. They report that this subtype differs from traditional MF, with a poorer prognosis (5 year survival 62\%), common follicular mucinosis and rare epidermotropism and often presentation in the head and neck area.

\section{New entities/subtypes}

Patients who have a diagnosis of CD5-positive B-cell lymphoproliferation often have MCL or CLL, and both diagnoses can be made in case the specific immunophenotype is present. If that is not so, the diagnosis can be difficult and it has been suggested that these lymphoproliferations may represent a disease entity. This hypothesis is nicely rejected by Dronca et al. [46] who selected 229 such cases and found that in all 61 patients who underwent a non-bone marrow tissue biopsy, a specific diagnosis could be made: CLL (44\%), marginal zone lymphoma (34\%), lymphoplasmacytic lymphoma (11\%), diffuse large B-cell lymphoma (8\%), and high-grade B-cell lymphoma not otherwise specified (2\%). In patients without such a biopsy a diagnosis could be made in only $25 \%$. Although flow cytometry on blood remains an important diagnostic tool, this study shows that when there is no straightforward diagnosis of CLL or MCL, a tissue biopsy is needed to come to the correct diagnosis.

Since the age of HIV infection, EBV-positive PCNSL have been recognized quite commonly. Although the incidence has sharply declined, EBV staining in PCNSL is commonly done. Sugite et al. [47] show that also in immune-competent patients, EBV-positive PCNSL can occur, a situation reminiscent to the EBV-positive DLBL of the elderly. They describe six cases of CNS DLBL with extensive necrosis and all are EBER and LMP-1-positive.

T/NK large granular lymphocyte leukemia (LGL) remains an enigmatic disease and has been described to be associated with B-cell neoplasia. Howard et al. [48] collected 56 patients with LGL and used a sensitive flowcytrometrical technique to detect clonal (i.e., light chain restricted) B-cell proliferations in these. They identified 16 patients (28\%) with abnormal B-cell populations; and characterized these abnormal B-cell populations as monoclonal B-cell lymphocytosis. It remains unclear what the clinical implication might be.

\section{Pitfalls in lymphoma diagnosis}

Kojima et al. [49] describe eight cases of follicular hyperplasia in biopsies taken after therapy for hematological malignancies. Such biopsies are nowadays more commonly taken since PET-scanning may reveal active lymph nodes and it is important to know whether indeed they represent remaining malignancy. The cases showed a remarkable follicular hyperplasia, with irregular follicles, which in a few cases where clonal by clonality testing. This should not come as a surprise since reactive follicles consist of limited number of clones which might be taken up by a sensitive clonality test [50]. Since the images resemble those seen in HIV-associated lymph node hyperplasia, a Tcell defect after chemotherapy might be the cause.

\section{Prognostic factors in lymphoma}

Studies on prognostic factors remain quite popular and also this review contains several studies that indicate important markers. Even though prognostic markers rarely enter routine practice, they may still be relevant for understanding diseases.

Steidl et al. [51] analyzed a relatively small series of HL ( $n=130$; which is small for a common disease that has a good prognosis for most patients) with expression arraying and found a macrophage signature to be prognostic (not surprisingly, since this is the case a many tumor types and already well known for HL). They confirmed the prognostic value in an independent series of 166 cases with immunohistochemistry. The discussion on this paper nicely points out that indeed the modern technology confirmed findings that were done in 1973 and were confirmed in 1983 and 1985 [52].

Sanchez-Espiridion et al. [53] come to a similar result by performing RT-PCR on formalin fixed tissue from HL 262 cases (20 were not successful) for genes known to be prognostic relevant. They were able to build a scoring system that was prognostically relevant in which, together with others, macrophage signature was the most important. They did not perform CD 68 staining however.

Barisil et al. [54] looked for the prognostic value of P53 and Cox-2 immunostaining in HL, but found only an associated with subtype, not with prognosis.

Array methods based on DNA are difficult in HL due to the low amount of tumor cells. Still, Steidl et al. [55] 
performed array CGH on microdissected tumor cells from 53 cases which were enriched for primary therapy refractory patients. Gains of chromosome 16p11.2-13.3 were significantly more frequent in pretreatment and relapse biopsies of unresponsive patients and were associated with shortened disease-specific survival. In the therapy-resistant $\mathrm{HL}$ cell line $\mathrm{KMH} 2$, they found genomic gains and overexpression of the multidrug resistance gene $\mathrm{ABCC} 1$ mapping to cytoband 16p13.11. Furthermore, they show that doxorubicin exposure to $\mathrm{KMH} 2$ induces $\mathrm{ABCC} 1$ expression and that siRNA silencing of $\mathrm{ABCC} 1$ sensitizes $\mathrm{KMH} 2$ cells to doxorubicin toxicity in vitro, suggesting that overexpression of $\mathrm{ABCC} 1$ contributes to the drug resistance phenotype found in $\mathrm{KMH} 2$. These findings therefore imply that gain of $16 \mathrm{p}$ may be a predictive factor for at least doxorubicin.

Increased vascularity in FL is known a well-known prognostic factor [56] but it is difficult to apply reliably in routine pathology. According to Clear et al. [57] angiogenic sprouting, as defined by the number of vessels smaller than $30 \mu \mathrm{m}$ is actually easier to assess, has better prognostic impact, and is associated with the amount of macrophages.

Chatzitolios et al. [58] performed immunohistochemistry using antibodies against the apoptosis-related proteins CD95, p53, and bcl-2 on 45 extranodal DLBL and 26 EMZL. They found that expression of CD95 indicated good prognosis in both groups and expression of bcl-2 indicated poor prognosis in DLBL, p53 in ENMZL. Troutaud et al. [58] used a similar approach, but selected patients so that also a predictive value for retuximab treatment could be estimated. In 46 DLBL patients treated with $\mathrm{CHOP}$, including 16 who also received rituximab, they found that $\mathrm{DAB}$ expression is associated with high stage and that apoptosis-inducing factor expression indicates longer survival when rituximab is given.

Myc rearrangement is the hallmark of BL, but occurs also in other B-cell lymphoma. Seegmiller et al. show that in MYC rearranged cases a simple karyotpye is indicating Burkitt's lymphoma, especially when there is also bcl-6 expression and that this is related to better survival. Montanari et al. [59] analyzed data from 72 patients with post-transplant lymphoproliferative disorder. Bone marrow involvement was seen in $23.5 \%$ of monomorphic cases and $15.7 \%$ of polymorphic cases. Although bone marrow involvement appeared independent of patient age, organ transplanted, Epstein-Barr virus status, and interval from transplantation to post-transplant lymphoproliferative disorder, or involvement of the grafted organ, it was significantly more frequent in cases without extranodal involvement; and it was associated with a significantly shorter survival. The incidence of bone marrow involvement in monomorphic post-transplant lymphoproliferative disorder (diffuse large B-cell lymphoma) was similar to that in HIV-associated diffuse large B-cell lymphoma, but higher than that in immunocompetent diffuse large B-cell lymphoma cases.

Nino et al. [60] determined the amount of macrophage in 42 cases of angioimmunoblastic T-cell lymphoma (AITL) using CD68 for all macrophages and CD163 for activated (M2) macrophages. The number of macrophages was not associated with survival, but a high ration CD163/CD68 indicated poor prognosis.

\section{Staging}

Musolino et al. [61] compared 51 simultaneous marrow aspirates and core biopsies from non-Hodgkin lymphoma patients for sensitivity, specificity, concordance, quality, and clinical relevance. The agreement level of bone marrow biopsy and bone marrow aspiration was $80 \%$, and the overall sensitivity and specificity for bone marrow aspiration were $69 \%$ and $86 \%$, respectively. When considering only the indolent non-Hodgkin lymphoma samples, the sensitivity of bone marrow aspiration was $82 \%$ and the specificity was $85 \%$, whereas the sensitivity and specificity were $40 \%$ and $86 \%$, respectively, in the aggressive nonHodgkin lymphoma specimens. Five cases $(10 \%)$ were reported in which bone marrow biopsy did not detect lymphoid infiltration even though the bone marrow aspiration was positive. These data indicate the complementarity of both methods.

\section{Ancillary techniques}

Schniederian et al. [62] compared the flow cytometric (FCL) profile of CD10-positive DLBL $(n=10)$ and BL $(n=13)$. Multiparameter FCI was performed using the following antibodies: CD18, CD20, CD43, CD44, and CD54 and isotype controls. Expression of CD44 and CD54 was detected at a significantly lower level in BL compared with CD10+ DLBCL. There was not a significant difference in expression of CD18 and CD43. The differences are however not large enough to introduce this method as substitute for standard pathology.

A guideline to assess the proliferative index in MCL was published in a previous volume of this Journal [63]. Nevertheless, it remains a cumbersome method. In an attempt to develop a more practical, reliable method Brizova et al. [64] investigated the value of a new quantitative technique for the assessment of Ki-67, and in addition, for topoisimerase II alpha and TPX2. They found that the method correlate well with standard immunohistochemistry with mib1 and also an association with cyclinD1 levels in MCL. 
Pax5 expression is now commonly used for determination of B-cell lineage, especially in immature B-cell neoplasms and HL; in the latter disease Pax 5 is weaker expressed than in B-lymphocytes that are normally present in the biopsy. Desouki et al. [65] investigated the value of Pax 5 immunostaining and found nuclear PAX-5 in $88 \%$ (36/41; no referral to weak expression was made) of HL, all cases of DLBL $(n=72)$, small B-cell lymphomas $(n=5)$, Blymphoblastic leukemia/lymphoma and mixed phenotype acute leukemia with B-cell lineage $(n=5)$. PAX-5 was not detected in ALCL $(n=22)$, T-cell lymphoblastic leukemia/ lymphoma, mixed phenotype acute leukemia with T-cell lineage $(n=5)$, acute myeloid leukemia $(n=4)$, carcinoid tumors with typical morphology $(n=5)$, melanoma $(n=3)$, and undifferentiated/metastatic tumors $(n=8)$. Nonneoplastic bone marrow sections showed scattered nuclear staining in small B-cell lymphocytes/hematogones. The detection of PAX-5 immunoreactivity resulted in the reclassification of two cases of ALCL to cHL. These data confirm the usefulness of this antibody in specific situations, while my own experience is that, especially in difficult cases of HL, it may be useful by the characteristic weak staining.

Clonality testing is a commonly used technique but is prone to mistakes in interpretation (see for instance Groenen et al. [66], and Langerak et al., [49]). Guzman et al. [67] determined whether a clonal B-cell population was present in the minor salivary glands of patients with Sjogren's syndrome $(n=60)$ and healthy controls [42]. They found a clonal population in $87 \%$ and $19 \%$ respectively, indicating indeed that reactive lesions may be clonal when a small B-cell population is present and that in autoimmune diseases a high percentage can be found due to the aberrant B-cell regulation. Another example of misinterpretation of results may be the report that indicated that tumor cells of Langerhans cell histiocytosis have clonally rearranged antigen receptors (both $\mathrm{B}$ - and $\mathrm{T}$; Chen et al. [68]); one could argue that these results are rather derived from bystander B- and T-cells. The other way around: Benharroch et al. [69] looked for the presence and amount of Langerhans cells in lymphomas and their significance. From a large series of lymphomas they selected 14 cases of HL with excess of Langerhans cells. These cases had more often EBV and p53 expression in Hodgkin cells, but no difference in prognosis.

An earlier study published in this journal [70] was confirmed by Burack et al. [71] who show that without micro dissection HL samples have often a detectable clonal B-cell population (23/47); using primers for the Kappadeleting element locus is more sensitive than using those for the framework regions.

Konoplevet al. [72] challenges the common idea that EMZL metastasize often to other extranodal sites as explanation that such patients regularly have multiple extranodal sites involved. In three of their four patients with multiple sites involved they showed that actually these were different clones and thus likely multiple primary tumors.

Kast et al. [73] use a completely different approach towards the diagnosis of tumors. They submitted blue round cell tumors, including lymphomas to Raman spectroscopy, a method by which the biochemical composition of tissues can be measured using laser. Using 32 samples they were able to build a classifier that consisted of ten peaks and classified all cases correctly. Obviously, this technique needs further testing, but might be an interesting new tool.

\section{References}

1. Timms AE, Horwitz MS (2010) KLHDC8B in Hodgkin lymphoma and possibly twinning. Commun Integr Biol 3:154-158

2. Huang X, van den Berg A, Gao Z, Visser L, Nolte I, Vos H, Hepkema B, Kooistra W, Poppema S, Diepstra A (2010) Expression of HLA class I and HLA class II by tumor cells in Chinese classical Hodgkin lymphoma patients. PLoS ONE 5: e10865

3. Osborne LC, Duthie KA, Seo JH, Gascoyne RD, Abraham N (2010) Selective ablation of the YxxM motif of IL-7Ralpha suppresses lymphomagenesis but maintains lymphocyte development. Oncogene 29:3854-3864

4. Craig VJ, Cogliatti SB, Arnold I, Gerke C, Balandat JE, Wündisch T, Müller A (2010) B-cell receptor signaling and CD40 ligand-independent $\mathrm{T}$ cell help cooperate in Helicobacterinduced MALT lymphomagenesis. Leukemia 24:1186-1196

5. Niino D, Yamamoto K, Tsuruta O, Maeda T, Yakushijin Y, Aoki R, Kimura Y, Hashikawa K, Kiyasu J, Takeuchi M, Sugita Y, Ohshima K (2010) Regression of rectal mucosa-associated lymphoid tissue (MALT) lymphoma after antibiotic treatments. Pathol Int 60:438-442

6. Masir N, Jones M, Lee AM, Goff LK, Clear AJ, Lister A, Marafioti T, Mason DY (2010) The expression of Bcl-2 by proliferating cells varies in different categories of B-cell lymphoma. Histopathology 56:617-626

7. Martín-Pérez D, Sánchez E, Maestre L, Suela J, Vargiu P, Di Lisio L, Martínez N, Alves J, Piris MA, Sánchez-Beato M (2010) Deregulated expression of the polycomb-group protein SUZ12 target genes characterizes mantle cell lymphoma. Am J Pathol 177:930-942

8. Leucci E, Cocco M, Onnis A, De Falco G, van Cleef P, Bellan C, van Rijk A, Nyagol J, Byakika B, Lazzi S, Tosi P, van Krieken H, Leoncini L (2008) MYC translocation-negative classical Burkitt lymphoma cases: an alternative pathogenetic mechanism involving miRNA deregulation. J Pathol 216:440-450

9. Di Lisio L, Gómez-López G, Sánchez-Beato M, Gómez-Abad C, Rodríguez ME, Villuendas R, Ferreira BI, Carro A, Rico D, Mollejo M, Martínez MA, Menárguez J, Díaz-Alderete A, Gil J, Cigudosa JC, Pisano DG, Piris MA, Martínez N (2010) Mantle cell lymphoma: transcriptional regulation by microRNAs. Leukemia 24:1335-1342

10. Dasmahapatra G, Lembersky D, Kramer L, Fisher RI, Friedberg J, Dent P, Grant S (2010) The pan-HDAC inhibitor vorinostat potentiates the activity of the proteasome inhibitor carfilzomib in human DLBCL cells in vitro and in vivo. Blood 115:4478-4487 
11. Baron BW, Hyjek E, Gladstone B, Thirman MJ, Baron JM (2010) PDCD2, a protein whose expression is repressed by BCL6, induces apoptosis in human cells by activation of the caspase cascade. Blood Cells Mol Dis 45:169-175

12. Cerchietti LC, Ghetu AF, Zhu X, Da Silva GF, Zhong S, Matthews M, Bunting KL, Polo JM, Farès C, Arrowsmith CH, Yang SN, Garcia M, Coop A, Mackerell AD Jr, Privé GG, Melnick A (2010) A small-molecule inhibitor of BCL6 kills DLBCL cells in vitro and in vivo. Cancer Cell 17:400

13. Tang W, Harmon P, Gulley ML, Mwansambo C, Kazembe PN, Martinson F, Wokocha C, Kenney SC, Hoffman I, Sigel C, Maygarden S, Hoffman M, Shores C (2010) Viral response to chemotherapy in endemic Burkitt lymphoma. Clin Cancer Res 16:2055-2064

14. Pechloff K, Holch J, Ferch U, Schweneker M, Brunner K, Kremer M, Sparwasser T, Quintanilla-Martinez L, Zimber-Strobl U, Streubel B, Gewies A, Peschel C, Ruland J (2010) The fusion kinase ITK-SYK mimics a $\mathrm{T}$ cell receptor signal and drives oncogenesis in conditional mouse models of peripheral $\mathrm{T}$ cell lymphoma. J Exp Med 207:1031-1044

15. Zha S, Bassing CH, Sanda T, Brush JW, Patel H, Goff PH, Murphy MM, Tepsuporn S, Gatti RA, Look AT, Alt FW (2010) ATM-deficient thymic lymphoma is associated with aberrant tcrd rearrangement and gene amplification. J Exp Med 5(207):1369 1380

16. Schlapbach C, Ochsenbein A, Kaelin U, Hassan AS, Hunger RE, Yawalkar N (2010) High numbers of DC-SIGN+dendritic cells in lesional skin of cutaneous T-cell lymphoma. J Am Acad Dermatol 62:995-1004

17. Kopp KL, Kauczok CS, Lauenborg B, Krejsgaard T, Eriksen KW, Zhang Q, Wasik MA, Geisler C, Ralfkiaer E, Becker JC, Ødum N, Woetmann A (2010) COX-2-dependent PGE(2) acts as a growth factor in mycosis fungoides (MF). Leukemia 24:1179-1185

18. Wetzels CT, Hoefnagel JG, Bakkers JM, Dijkman HB, Blokx WA, Melchers WJ (2009) Ultrastructural proof of polyomavirus in Merkel cell carcinoma tumour cells and its absence in small cell carcinoma of the lung. PLoS ONE 4(3):e4958

19. Andres C, Puchta U, Sander CA, Ruzicka T, Flaig MJ. Prevalence of Merkel cell polyomavirus DNA in cutaneous lymphomas, pseudolymphomas, and inflammatory skin diseases. Am J Dermatopathol. 2010 Jun 9. In press. PubMed PMID: 20534985.

20. Iyengar P, Mazloom A, Shihadeh F, Berjawi G, Dabaja B. Hodgkin lymphoma involving extranodal and nodal head and neck sites: characteristics and outcomes. Cancer. 2010 May 17, in press PubMed PMID: 20564093.

21. Larouche JF, Berger F, Chassagne-Clément C, Ffrench M, CalletBauchu E, Sebban C, Ghesquières H, Broussais-Guillaumot $F$, Salles G, Coiffier B (2010) Lymphoma recurrence 5 years or later following diffuse large B-cell lymphoma: clinical characteristics and outcome. J Clin Oncol 28:2094-2100

22. Mwakigonja AR, Kaaya EE, Heiden T, Wannhoff G, Castro J, Pak F, Porwit A, Biberfeld P (2010) Tanzanian malignant lymphomas: WHO classification, presentation, ploidy, proliferation and HIV/ EBV association. BMC Cancer 10:344

23. Tumwine LK, Orem J, Kerchan P, Byarugaba W, Pileri SA (2010) EBV, HHV8 and HIV in B cell non Hodgkin lymphoma in Kampala, Uganda. Infect Agent Cancer 5:12

24. Li T, Medeiros LJ, Lin P, Yin $\mathrm{H}$, Littlejohn $\mathrm{M}$, Im W, Lennon PA, Hu P, Jorgensen JL, Liang M, Guo H, Yin CC (2010) Immunohistochemical profile and fluorescence in situ hybridization analysis of diffuse large B-cell lymphoma in northern China. Arch Pathol Lab Med 134:759-765

25. van Krieken JH (2010) New developments in the pathology of malignant lymphoma. A review of the literature published from Jan 2010-April 2010. J Hematop 3:47-58
26. Sun TQ, Zhu XL, Wang ZY, Wang CF, Zhou XY, Ji QH, Wu Y (2010) Characteristics and prognosis of primary thyroid nonHodgkin's lymphoma in Chinese patients. J Surg Oncol 101:545-550

27. Takasaki Y, Iwanaga M, Imaizumi Y, Tawara M, Joh T, Kohno T, Yamada Y, Kamihira S, Ikeda S, Miyazaki Y, Tomonaga M, Tsukasaki K (2010) Long-term study of indolent adult T-cell leukemia-lymphoma. Blood 115:4337-4343

28. Liao JB, Chuang SS, Chen HC, Tseng HH, Wang JS, Hsieh PP (2010) Clinicopathologic analysis of cutaneous lymphoma in Taiwan: a high frequency of extranodal natural killer/T-cell lymphoma, nasal type, with an extremely poor prognosis. Arch Pathol Lab Med 134:996-1002

29. Andréasson U, Edén P, Peterson C, Högerkorp CM, Jerkeman M, Andersen N, Berglund M, Sundström C, Rosenquist R, Borrebaeck CA, Ek S (2010) Identification of uniquely expressed transcription factors in highly purified B-cell lymphoma samples. Am J Hematol $85: 418-425$

30. Kojima M, Nakamura N, Itoh H, Shimizu K, Shimizu K, Matsuda H, Tamaki Y, Masawa N, Nakamura S (2010) Epstein-Barr virusrelated atypical lymphoproliferative disorders in Waldeyer's ring: a clinicopathological study of 9 cases. Pathobiology 77:218-224

31. Liu TY, Dei PH, Kuo SH, Lin CW (2010) Early low-grade gastric MALToma rarely transforms into diffuse large cell lymphoma or progresses beyond the stomach and regional lymph nodes. J Formos Med Assoc 109:463-471

32. Kraus TS, Sillings CN, Saxe DF, Li S, Jaye DL (2010) The role of CD11c expression in the diagnosis of mantle cell lymphoma. Am J Clin Pathol 134:271-277

33. Rizzo KA, Streubel B, Pittaluga S, Chott A, Xi L, Raffeld M, Jaffe ES (2010) Marginal zone lymphomas in children and the young adult population; characterization of genetic aberrations by FISH and RT-PCR. Mod Pathol 23:866-873

34. Durnick DK, Law ME, Maurer MJ, Natkunam Y, Levy R, Lossos IS, Kurtin PJ, McPhail ED (2010) Expression of LMO2 is associated with $\mathrm{t}(14 ; 18) / \mathrm{IGH}-\mathrm{BCL} 2$ fusion but not BCL6 translocations in diffuse large B-cell lymphoma. Am J Clin Pathol 134:278-281

35. Vajpayee N, Hussain J, Tolocica I, Hutchison RE, Gajra A. Expression of signal transducer and activator of transcription 3 (STAT3) in primary central nervous system diffuse large B-cell lymphoma: a retrospective analysis of 17 cases. J Neurooncol. 2010, in press

36. Montes-Moreno S, Gonzalez-Medina AR, Rodriguez-Pinilla SM, Maestre L, Sanchez-Verde L, Roncador G, Mollejo M, García JF, Menarguez J, Montalbán C, Ruiz-Marcellan MC, Conde E, Piris MA (2010) Aggressive large B-cell lymphoma with plasma cell differentiation: immunohistochemical characterization of plasmablastic lymphoma and diffuse large B-cell lymphoma with partial plasmablastic phenotype. Haematologica 95:1342-1349

37. Taddesse-Heath L, Meloni-Ehrig A, Scheerle J, Kelly JC, Jaffe ES (2010) Plasmablastic lymphoma with MYC translocation: evidence for a common pathway in the generation of plasmablastic features. Mod Pathol 23:991-999

38. May PC, Foot N, Dunn R, Geoghegan H, Neat MJ (2010) Detection of cryptic and variant IGH-MYC rearrangements in high-grade non-Hodgkin's lymphoma by fluorescence in situ hybridization: implications for cytogenetic testing. Cancer Genet Cytogenet 198:71-75

39. Kelemen K, Braziel RM, Gatter K, Bakke TC, Olson S, Fan G (2010) Immunophenotypic variations of Burkitt lymphoma. Am J Clin Pathol 134:127-138

40. Ruzinova MB, Caron T, Rodig SJ (2010) Altered subcellular localization of c-Myc protein identifies aggressive B-cell lymphomas harboring a c-MYC translocation. Am J Surg Pathol 34:882-891

41. Stasik CJ, Nitta H, Zhang W, Mosher CH, Cook JR, Tubbs RR, Unger JM, Brooks TA, Persky DO, Wilkinson ST, Grogan TM, 
Rimsza LM (2010) Increased MYC gene copy number correlates with increased mRNA levels in diffuse large B-cell lymphoma. Haematologica 95:597-603

42. Gerami P, Wickless SC, Querfeld C, Rosen ST, Kuzel TM, Guitart J (2010) Cutaneous involvement with marginal zone lymphoma. J Am Acad Dermatol 63:142-145

43. Koens L, Vermeer MH, Willemze R, Jansen PM (2010) IgM expression on paraffin sections distinguishes primary cutaneous large B-cell lymphoma, leg type from primary cutaneous follicle center lymphoma. Am J Surg Pathol 34:1043-1048

44. Bhagavathi S, Blenc AM, Amin M, Nikitin VD, Patel MC, Warren S, Malhotra RK (2010) Primary cutaneous large B-cell lymphoma shows activation of nuclear factor kappa B and low incidence of Epstein-Barr virus. Am J Dermatopathol 32:439-441

45. Lehman JS, Cook-Norris RH, Weed BR, Weenig RH, Gibson LE, Weaver AL, Pittelkow MR (2010) Folliculotropic mycosis fungoides: single-center study and systematic review. Arch Dermatol 146:607-613

46. Dronca RS, Jevremovic D, Hanson CA, Rabe KG, Shanafelt TD, Morice WG, Call TG, Kay NE, Collins CS, Schwager SM, Slager SL, Zent CS. CD5-positive chronic B-cell lymphoproliferative disorders: Diagnosis and prognosis of a heterogeneous disease entity. Cytometry B Clin Cytom. 2010, in press

47. Sugita Y, Terasaki M, Niino D, Ohshima K, Fumiko A, Shigemori M, Sato Y, Asano N. Epstein-Barr virus-associated primary central nervous system lymphomas in immunocompetent elderly patients: analysis for latent membrane protein-1 oncogene deletion and EBNA-2 strain typing. J Neurooncol. 2010, in press

48. Howard MT, Bejanyan N, Maciejewski JP, Hsi ED (2010) T/NK large granular lymphocyte leukemia and coexisting monoclonal B-cell lymphocytosis-like proliferations. An unrecognized and frequent association. Am J Clin Pathol 133:936-941

49. Kojima M, Nakamura N, Murayama K, Igarashi T, Matsumoto M, Matsuda H, Masawa N, Miura I, Morita Y (2010) Reactive lymphoid hyperplasia with giant follicles associated with a posttherapeutic state of hematological malignancies. A report of eight cases. Tumori 96:143-148

50. Langerak AW, Molina TJ, Lavender FL, Pearson D, Flohr T, Sambade C, Schuuring E, Al Saati T, van Dongen JJ, van Krieken JH (2007) Polymerase chain reaction-based clonality testing in tissue samples with reactive lymphoproliferations: usefulness and pitfalls. A report of the BIOMED-2 Concerted Action BMH4CT98-3936. Leukemia 21:222-229

51. Steidl C, Lee T, Shah SP, Farinha P, Han G, Nayar T, Delaney A, Jones SJ, Iqbal J, Weisenburger DD, Bast MA, Rosenwald A, Muller-Hermelink HK, Rimsza LM, Campo E, Delabie J, Braziel RM, Cook JR, Tubbs RR, Jaffe ES, Lenz G, Connors JM, Staudt LM, Chan WC, Gascoyne RD (2010) Tumorassociated macrophages and survival in classic Hodgkin's lymphoma. N Engl J Med 362:875-885

52. Kadin ME (2010) Macrophages in Hodgkin's lymphoma. N Engl J Med 362:2135-2136, author reply 2136

53. Sánchez-Espiridión B, Montalbán C, López A, Menárguez J, Sabín P, Ruiz-Marcellán C, Lopez A, Ramos R, Rodríguez J, Cánovas A, Camarero C, Canales M, Alves J, Arranz R, Acevedo A, Salar A, Serrano S, Bas A, Moraleda JM, Sánchez-Godoy P, Burgos F, Rayón C, Fresno MF, García Laraña J, García-Cosío M, Santonja C, López JL, Llanos M, Mollejo M, González-Carrero J, Marín A, Forteza J, García-Sanz R, Tomás JF, Morente MM, Piris MA, García JF. A molecular risk score based on four functional pathways for advanced classical Hodgkin lymphoma. Blood. 2010 , in press

54. Barisik NO, Bozkurt S, Gumus M, Kaygusuz I, Karadayi N, Bas E, Bayik M, Tecimer T (2010) Expression and prognostic significance of Cox-2 and p-53 in Hodgkin lymphomas: a retrospective study. Diagn Pathol 5:19
55. Steidl C, Telenius A, Shah SP, Farinha P, Barclay L, Boyle M, Connors JM, Horsman DE, Gascoyne RD (2010) Genome-wide copy number analysis of Hodgkin Reed-Sternberg cells identifies recurrent imbalances with correlations to treatment outcome. Blood 116:418-427

56. Koster A, van Krieken JH, Mackenzie MA, Schraders M, Borm GF, van der Laak JA, Leenders W, Hebeda K, Raemaekers JM (2005) Increased vascularization predicts favorable outcome in follicular lymphoma. Clin Cancer Res 11:154-161

57. Clear AJ, Lee AM, Calaminici M, Ramsay AG, Morris KJ, Hallam S, Kelly G, Macdougall F, Lister TA, Gribben JG (2010) Increased angiogenic sprouting in poor prognosis FL is associated with elevated numbers of CD163+ macrophages within the immediate sprouting microenvironment. Blood 115:5053-5056

58. Chatzitolios A, Venizelos I, Tripsiannis G, Anastassopoulos G, Papadopoulos N (2010) Prognostic significance of CD95, P53, and BCL2 expression in extranodal non-Hodgkin's lymphoma. Ann Hematol 89:889-896

59. Montanari F, O'Connor OA, Savage DG, Zain JM, Venkatraman S, McCormick EK, Crook MT, Tsao L, Sevilla DW, Bhagat G, Alobeid B (2010) Bone marrow involvement in patients with posttransplant lymphoproliferative disorders: incidence and prognostic factors. Hum Pathol 41:1150-1158

60. Niino D, Komohara Y, Murayama T, Aoki R, Kimura Y, Hashikawa K, Kiyasu J, Takeuchi M, Suefuji N, Sugita Y, Takeya M, Ohshima K (2010) Ratio of M2 macrophage expression is closely associated with poor prognosis for angioimmunoblastic Tcell lymphoma (AITL). Pathol Int 60:278-283

61. Musolino A, Guazzi A, Nizzoli R, Panebianco M, Mancini C, Ardizzoni A (2010) Accuracy and relative value of bone marrow aspiration in the detection of lymphoid infiltration in non-Hodgkin lymphoma. Tumori 96:24-27

62. Schniederjan SD, Li S, Saxe DF, Lechowicz MJ, Lee KL, Terry PD, Mann KP (2010) A novel flow cytometric antibody panel for distinguishing Burkitt lymphoma from CD10+ diffuse large B-cell lymphoma. Am J Clin Pathol 133:718-726

63. Klapper W, Hoster E, Determann O, Oschlies I, van der Laak J, Berger F, Bernd HW, Cabeçadas J, Campo E, Cogliatti S, Hansmann ML, Kluin PM, Kodet R, Krivolapov YA, Loddenkemper C, Stein H, Möller P, Barth TE, Müller-Hermelink K, Rosenwald A, Ott G, Pileri S, Ralfkiaer E, Rymkiewicz G, van Krieken JH, Wacker HH, Unterhalt M, Hiddemann W, Dreyling M, European MCL Network (2009) $\mathrm{Ki}-67$ as a prognostic marker in mantle cell lymphomaconsensus guidelines of the pathology panel of the European MCL Network. J Hematop 2:103-111

64. Brizova H, Kalinova M, Krskova L, Mrhalova M, Kodet R (2010) A novel quantitative PCR of proliferation markers (Ki-67, topoisomerase IIalpha, and TPX2): an immunohistochemical correlation, testing, and optimizing for mantle cell lymphoma. Virchows Arch 456:671-679

65. Desouki MM, Post GR, Cherry D, Lazarchick J (2010) PAX-5: a valuable immunohistochemical marker in the differential diagnosis of lymphoid neoplasms. Clin Med Res 8:84-88

66. Groenen PJ, Langerak AW, van Dongen JJ, van Krieken JH (2008) Pitfalls in TCR gene clonality testing: teaching cases. J Hematop 1:97-109

67. Guzmán LM, Castillo D, Aguilera SO (2010) Polymerase chain reaction (PCR) detection of B cell clonality in Sjögren's syndrome patients: a diagnostic tool of clonal expansion. Clin Exp Immunol 161:57-64

68. Chen W, Wang J, Wang E, Lu Y, Lau SK, Weiss LM, Huang Q (2010) Detection of clonal lymphoid receptor gene rearrangements in Langerhans cell histiocytosis. Am J Surg Pathol 34:1049-1057

69. Benharroch D, Guterman G, Levy I, Shaco-Levy R (2010) High content of Langerhans cells in malignant lymphoma-incidence and significance. Virchows Arch 457:63-67 
70. Hebeda KM, Van Altena MC, Rombout P, Van Krieken JH, Groenen PJ (2009) PCR clonality detection in Hodgkin lymphoma. J Hematop 2:34-41

71. Burack WR, Laughlin TS, Friedberg JW, Spence JM, Rothberg PG (2010) PCR assays detect B-lymphocyte clonality in formalin-fixed, paraffin-embedded specimens of classical Hodgkin lymphoma without microdissection. Am J Clin Pathol 134:104-111
72. Konoplev S, Lin P, Qiu X, Medeiros LJ, Yin CC (2010) Clonal relationship of extranodal marginal zone lymphomas of mucosaassociated lymphoid tissue involving different sites. Am J Clin Pathol 134:112-118

73. Kast R, Rabah R, Wills H, Poulik J, Auner GW, Klein MD (2010) Differentiation of small round blue cell tumors using Raman spectroscopy. J Pediatr Surg 45:1110-1114 